\title{
Dyskursywne konstruowanie wiedzy zgodnie z logiką budowania męskiego habitusu uczniów w klasie szkolnej
}

\begin{abstract}
Postęp nie jest natychmiast rozkoszą, dobrobytem ani spokojem. Nie jest odpoczynkiem. [...] sam przez się jest dobrem. [...] Jest świadomością wszystkiego, co istnieje i wszystkiego, co możliwe.
\end{abstract}

P.T. de Chardin, O postępie

Zagadnienie funkcji języka oraz „filozofii” jego użycia ma zasadnicze znaczenie dla zrozumienia, w jaki sposób dokonuje się jego nabywanie oraz jak jest on pierwotnie używany. Sposób mówienia jest przyswajany jako narzędzie regulacji zarówno wspólnego zwracania na coś uwagi (joint attention), jak i wspólnego działania (joint action). Funkcje te znajdują odbicie w samej strukturze języka, a także w procesie jego przyswajania przez uczennice i uczniów. Hierarchizacja rodzajowa obserwowana w języku podmiotów edukacji nie jest „wrodzonością" językową, lecz stanowi zespół specyficznych cech uwagi, działania ludzkiego, sposobu użycia języka oraz wymiaru widzenia i rozumienia otaczającej rzeczywistości w języku i poprzez język (Bruner 1980). Rozwój będący celem wychowania (Kohlberg, Mayer 1993 , s. 55-93) wraz z procesem językowego konstruowania wiedzy, zakorzenionym $\mathrm{w}$ algorytmie budowania habitusu męskiego, w sposób szczególny odnosi się do dobra, jakim jest postęp podmiotów edukacji w sposobie widzenia dyskursu szkolnej modalności możliwości oraz przymusu.

Prymarne miejsce $\mathrm{w}$ rozważaniach nad wynikami eksplanacji i interpretacji materiału empirycznego, opartego na krytycznej analizie dyskursu, obok zhierarchizowanego rodzajowo języka, zajmują związane z nim i uwikłane w pole klasy szkolnej podmioty. Dla konstruowania wiedzy w klasie szkolnej gruntem jest komunikacyjne środowisko nauczania i uczenia się, w którym funkcję kierowniczą pełni nauczyciel. Podchodzący w sposób tradycyjny do pedagogicznych działań dostrzega on trzy najważniejsze swoje zadania. Pierwsze z nich to bardziej monologowe niż dialogowe przekazywanie wiedzy "gotowej", „absolutnej", zamkniętej oraz ograniczonej niefrasobliwością nauczycielską. Kolejnym, chyba najbardziej ulubionym, zadaniem nauczyciela jest codzienne realizowanie swej 
pedagogicznej skuteczności w utrzymywaniu dyscypliny w klasie szkolnej, która bezpośrednio wiąże się z ocenianiem oraz krytykowaniem stanu wiedzy, a także wszelkich działań i zachowań uczennic oraz uczniów. Wreszcie ostatnie, skuteczne i efektywne działanie, którego w swoim sposobie patrzenia nauczycielki i nauczyciele nie dostrzegają, to dyskursywne utrwalanie polaryzacji rodzajowej wraz z konstruowaniem habitusów rodzajowych dziewcząt oraz chłopców w procesie "specyficznego" tworzenia wiedzy podczas lekcji.

Dotychczasowe wyniki badań pokazują, że genderowe różnice i podobieństwa są nie tylko efektami socjalizacji domowej, ale również "gramatycznej" socjalizacji w przestrzeni szkoły z udziałem [nie]świadomości nauczycieli i nauczycielek oraz braku ich uważnej kontroli własnych praktyk komunikacyjnych w tym zakresie (Howe 1997, s. 44; Swann 2008, s. 625; Sunderland 2000, s. 149-173; Karwatowska, Szpyra-Kozłowska 2005, s. 139; Bochno 2009, s. 181; Putkiewicz 2002, s. 107; Pankowska 2004, s. 99; Kruszewski 1993; Konarzewski 1991, s. 144). Warto podkreślić, iż zdaniem Aleksandra Sztejnberga zgodnie z koncepcją nauczania zorientowanego na wychowanka nauczycielki i nauczyciele starają się ułatwić im uczenie się (Sztejnberg 2006, s. 17). Zatem ich działania ukierunkowane są na konstruowanie przez dziewczęta i chłopców wiedzy oraz jej użyteczność w „etnograficznym $^{1}$ skansenie" dyskursu szkolnego.

Projektem badawczym osadzonym w etnografii komunikacji objęci zostali i zostały głównie uczniowie i uczennice w wieku 12-13 lat. Dydaktyce nie jest obojętne, co dzieje się z dziećmi w okresie operacji formalnych, kiedy są zdolne do logicznego rozwiązywania abstrakcyjnych problemów oraz weryfikowania hipotez na poziomie werbalnym wraz z antycypowaniem ich następstw (Piaget 1996) $\mathrm{w}$ procesie nauczania i uczenia się. $\mathrm{W}$ jaki zatem sposób nauczycielki i nauczyciele konstruują wrażliwość zmysłów uczniów na wiedzę, aspiracje, motywacje?

Atmosfera poniżania nie służy podniesieniu motywacji zarówno nauczycieli, jak i uczniów. Słowa i elementy, które im towarzyszą, niosące potencjał powodowania cierpienia osoby, do której są kierowane, są sposobem zwracania się, który interpeluje, określa, szufladkuje/pozycjonuje i ustanawia określony podmiot. Zlekceważony oraz poniżony człowiek, uczeń, przyszły mężczyzna za sprawą wypowiedzianego przezwiska oraz stojących za nim intencji zostaje umiejscowiony i wprowadzony do określonego logiką uJarzmiania (Foucault 2009) miejsca/punktu w czasoprzestrzeni społecznej. Taki akt ogranicza możliwość społecznego istnienia, którą dana interpelacja wyklucza. Akty illokucyjne niemal natychmiast, poprzez samo wypowiedzenie, skutecznie czynią to, co zostało wypowiedziane.

$\mathrm{Nl} / \mathrm{K}^{2}$ : Co z ciebie będzie za mężczyzna!?

1 „Etnograficznym”, ponieważ badania empiryczne oparte są na etnografii komunikacji urzeczywistnianej w klasie szkolnej.

$2 \mathrm{Nl} / \mathrm{K}$ - Nauczycielka/kobieta, Nl/M - nauczyciel/mężczyzna, Litera/M (mężczyzna) po ukośniku - chłopiec (uczeń) lub nauczyciel, np. J/M, Litera/K (kobieta) - dziewczyna (uczennica) lub nauczycielka, np. N/K. 
Prezentowany wyżej akt perlokucyjny ma potencjał wywoływania skutków pojawiających się jednak nieco później niż w chwili wypowiadania. Prowadzi zatem do pewnych konsekwencji, które nie są takie same i nie opisują wprost mających pojawić się w okresie późniejszym efektów.

Kategoria płci kulturowej (gender) wiąże się ze sposobem przedstawiania oraz konstruowania męskości i kobiecości oraz odgrywaniem związanych z tymi kategoriami ról (Barker 2005, s. 519). Płeć to jedno z głównych pojęć w przestrzeni rozumienia rzeczywistości społecznej (Bruner 1988), a także w płaszczyźnie tworzenia się męskiego habitusu rodzajowego. Teoria społecznego uczenia się wyjaśnia, iż kształtowanie się rodzaju przebiega podobnie jak inne typy wyuczonego zachowania. Przyjąć więc można, że dobrze byłoby zaliczyć rodzaj do zachowań niezdeterminowanych biologicznie, lecz nabytych (Brannon 2002, s. 183). Proces kształtowania się męskości rozpoczyna się w chwili narodzin osobnika płci męskiej i trwa przez całe jego życie. Bardzo duży wpływ na postać oraz wymiar kategorii, jaką jest męski habitus, ma zespół praktyk komunikacyjnych produkowanych, a przede wszystkim reprodukowanych w klasie szkolnej. Habitus rodzajowy składa się z trwałych, przekładalnych dyspozycji oraz ustrukturowanych struktur z potencjałem strukturującym, które funkcjonują jako generatory określające i tworzące praktyki oraz wyobrażenia. Ich „zawartość” związana jest celem, który nie musi być przez jednostki uświadamiany, ale jednocześnie powinien predestynować do opanowania instrukcji i sposobów umożliwiających jego osiąganie. Owy cel uwikłany jest w obiektywną regularność, regulacje i kolektywne stanowienie (Bourdieu 2008).

Habitusowe dyspozycje zostały osadzone i skutecznie wpojone przez możliwości oraz niemożliwości, swobody i konieczność, przyzwolenia i zakazy. Uczeń zakorzeniony jest w szkolnej logice tego, co odrzucone, która skłania do podążania za tym, co jawi się jako nieuniknione. Obiekty funkcjonujące w polu społecznym, ich intuicje, odwaga, lęk i realizujące się mechanizmy są "tylko" i zarazem "aż" tworami konstruowanymi społecznie. Medal, który z jednej strony posiada wygrawerowaną „naturalność”, z drugiej zaś oświetlone latarnią aktów performatywnych „wyczucie miejsca” ${ }^{3}$, jest nagrodą, jaką oferuje przemoc symboliczna za uleganie „illusio" ${ }^{4}$. Do współpracy na rzecz urzeczywistniania się polityki męskiego habitusu zaprzęgnięta została owa praktyczna wiara, jako gwarant jej wysokiej jakości i skuteczności. W rozważaniach nad habitusem nie sposób pominąć faktu, iż jest on produktem historii oraz schematów przez nią przedstawianych. Zarówno jednostkowe, jak i zbiorowe praktyki z zawartymi w nich elementami przejawiają się dzięki aktywnej obecności minionych doświadczeń w postaci schematów postrzegania, myślenia i działania.

3 Wyczucie miejsca - kategoria pochodząca z teorii społecznej Bourdieu.

4 Illusio - jedna $\mathrm{z}$ kategorii należąca do teorii społecznej Bourdieu, oznaczająca dobrze ugruntowane przekonanie (dobrą wiarę), że czyni się dobrze oraz że działania innych podmiotów pola społecznego są również właściwe oraz zgodne z jego (pola) logiką. 
Nl/K: Basia, ty jesteś Patryk? Na litość boską! Jak macie mówić, nie mówicie, a jak macie się nie odzywać, to niepytani nadajecie.

W prezentowanym powyżej fragmencie nauczycielskiej wypowiedzi usłyszeć można irytację połączoną z podkreśleniem fenomenu uczniowskiej niesubordynacji: „jak mają mówić, to nie mówią”, a kiedy mają milczeć, to "nadają". Ponadto $\mathrm{w}$ taki sposób konstruowana wypowiedź oraz atmosfera uczenia się być może potrzebuje raczej namysłu i litości nauczycieli niż „litości boskiej”. Basia odważyła się zabrać głos bez podniesienia ręki, co może ewentualnie być zaakceptowane przez nauczycielkę w odniesieniu do ucznia (chłopca), lecz nie uczennicy.

Interakcja uczniów i uczennic z nauczycielką oraz wiedzy z władzą realizuje się poprzez codzienne powtarzalne utrwalanie porządku dyscyplinarnego (Foucault 2009), zgodnego z koncepcją „ujarzmiania” podmiotu Michela Foucault. Ów ład, podobnie jak naczynia kapilarne, przenika wszystko, co usytuowane jest $\mathrm{w}$ polu klasy szkolnej, traktowanym jako pole społeczne w rozumieniu teorii społecznej Pierre'a Bourdieu. W kategorii „wszystko" zawiera się zachowanie się w ławce szkolnej, punktualność, konstruowane habitusy rodzajowe, utrwalana hierarchizacja rodzajowa, sposób mówienia, a przede wszystkim sposób wytwarzania wiedzy przez uczniów oraz uczennice.

Przyglądając się tradycyjnemu paradygmatowi, w jaki uwikłana jest męskość, zauważamy w nim pęknięcia i kruszące się elementy jego konstrukcji. Jednym z dowodów takiego procesu jest "znacząca relatywizacja kategorii męskości" ${ }^{\prime 5}$ [Melosik 2006, s. 9]. Jeżeli przyjmie się założenie, iż kryzys męskości jest faktem społecznym, to dobrze byłoby poszukać jego przyczyn poza procesem emancypacji kobiet i zastanowić się, w jaki sposób owa kategoria jest konstruowana w szkole podstawowej. $Z$ dużym prawdopodobieństwem można założyć, iż jest on zakorzeniony w sposobie codziennego, regularnego, opartego na powtarzalności praktyk komunikacyjnych, konstruowania męskiego habitusu w polu szkoły.

N/K: Powiem tak, że on nie potrafił utrzymać się w żadnej pracy.

$\mathrm{P} / \mathrm{M}:$ Jak to?

$\mathrm{N} / \mathrm{K}$ : To jest też jego minus. Ale w takim krótkim czasie ....

$\mathrm{Nl} / \mathrm{K}$ (przerywając wypowiedź $\mathrm{N} / \mathrm{K})$ : [...] Nie widzi dla siebie miejsca, tak? [...] To oto chodzi w życiu, tak, żeby się człowiek nie męczył i dobrze wykonywał swoje zadania.

Powyższy fragment może odzwierciedlać frustrację i skłonność mężczyzn do depresji, którzy mają niekiedy trudności z odnalezieniem swojego miejsca w rzeczywistości społecznej. Procesowi temu, wraz z dysonansem poznawczym, towarzyszy rodzący się opór uczniów, którzy w kontekście relatywizacji kategorii męs-

5 W swoim referacie Kryzys męskości czy szansa dla mężczyzn? Przegląd problematyki badań Krzysztof Arcimowicz stwierdził, iż kategoria ta odnosi się do przemian i ewolucji oraz stanowi raczej produkt dyskursu niezasługujący na rangę realnego problemu. Takie stanowisko zaprezentowane zostało podczas Ogólnopolskiej Interdyscyplinarnej Konferencji Naukowej „Seksualność, męskość, edukacja. Panika moralna 2013/2014 - rekonstrukcje" w Gdańsku w dniu 5.10.2014 r. 
kości pojawiającej się poza murami szkoły odczuwają frustrację (Galasiński 2008a, s. 153, 176) oraz niechęć do szkoły (Melosik 2006, s. 8). Z dużym prawdopodobieństwem można założyć, że tego typu emocje mają swoje przełożenie na sposób patrzenia na swoje życie osobiste i zawodowe uczniów - przyszłych mężczyzn (Galasiński 2008b, s. 71-72).

[...] Bo chłopcy są jacyś tacy bardziej wrażliwi na swoją dumę. Bo jak dziewczyna się pomyli, to się uśmiechnie i pójdzie dalej, a chłopiec jak się pomyli to, od razu robi mu się głupio, bo dziewczyny widziały, że wyszedłem na głąba. Może po sobie też trochę patrzę, więc może to jest kwestia tego, ale może. (WH/M)

\section{[...] Są tacy ograniczeni przez to wszystko, co jest. (WP/K)}

Nauczycielki i nauczyciele w ramach "oficjalnego dyskursu pedagogicznego" poddają się sieci stereotypów, działając zgodnie z „cichą polityką” konstruowania habitusu męskiego (Kopciewicz 2003). Szkoła jest miejscem, gdzie jednym nakazuje się milczeć i nie myśleć, a drugich zachęca się do mówienia oraz aktywności intelektualnej, kreśląc grubą linię pomiędzy mało zdolną matematycznie uczennicą a bystrym oraz inteligentnym, przede wszystkim w zakresie nauk ścisłych, uczniem (Kopciewicz 2007, s. 13-14).

W polu klasy szkolnej w ramach dyskursywnego odtwarzania rodzaju męskiego zgodnie z tradycyjną "gramatyką" socjalizacyjną równolegle toczą się dwa procesy: tworzenia się kobiecego habitusu oraz konstruowania męskiego habitusu. Udział nauczycieli w przyswajaniu ról płciowych realizuje się poprzez bezpośrednie, codzienne interakcje uczniów z nauczycielem, stanowiąc ważny czynnik socjalizacyjny edukacji szkolnej (Barnes 1988, s. 10-12). Ich zachowania i praktyki komunikacyjne mają duże znaczenie dla tworzenia habitusów rodzajowch i utrwalania ról płciowych w procesie szkolnej socjalizacji uczniów (Melosik 2006, s. 188-189), a także dla jakości wiedzy, która rodzi się w szkole.

Zhierarchizowany rodzajowo język ogranicza wiedzę, narzucając granice możliwości nadawania znaczeń oraz wytyczając zbiór znaczeń „właściwych”, które nie podlegają dyskusji, jednocześnie definiując zbiór znaczeń zakazanych. Przyjęty sposób używania języka wytycza drogi do zdobywania wiedzy, kształtuje tendencje poznawcze determinowane prawami postrzegania. Zarządzający sytuacjami mówienia nauczyciel posiada umiejętność skutecznego ich bodźcowania do rozwoju uczniowskich kompetencji.

$\mathrm{Nl} / \mathrm{K}:$ Ja mam wrażenie czasami, że wy im macie więcej lat ...

$\mathrm{P} / \mathrm{K}$ : Tym mniej używamy rozumu. (Nauczycielka kiwa potakująco głową).

[...] Widać to przygotowanie, bo jest kilkoro uczniów, no dwójka czy trójka, które twierdzą, rodzice też, że faktycznie się zawsze przygotowują, no, ale pewne rzeczy im nie wchodzą, nie wychodzą, nie potrafią nic. No jakaś tam praca jest włożona, ale może zostało im trochę do lepszych efektów. (WS/K)

Od razu wyzwiska lecą, że on jest głupi i tępy, że jak można tego nie wiedzieć, jak można to zepsuć, przecież to jest takie łatwe i jakby osądzają siebie już nie mówiąc, 
że nie patrzą, że jak oni idą do tablicy to też nie wszystko robią dobrze tak, więc tu jest ten problem, że oni u siebie nie widzą, a u kogoś od razu. (WS/K)

Zwykle w szkole zakłada się dość niską ciekawość poznawczą uczennic, dlatego częściej efektywniej aktywizuje się chłopców do popisywania się swoją wiedzą, konstruowaną jednakże zgodnie z zaleceniami nauczyciela. Niezależność w samodzielnym procesie uczenia się uczniów w klasie szkolnej jest „dobrem rzadkim" $^{\prime \prime}$, którego prawie całkowicie pozbawione są uczennice. Zarządzający „aktywnością" wiedzy w klasie szkolnej jawią się bardziej jako nadzorujący krytycy niż konsultanci zachęcający do podejmowania inicjatyw i rozwijania uczniowskiej swobodnej spontaniczności w poszukiwaniu dróg do nadawania znaczeń, konstruowanemu każdego dnia obrazowi poznawanej rzeczywistości.

[...] że nie jest to tylko taka wiedza, którą przekazujemy tylko podręcznikowo, [...] więc wszystko zależy od tego oczywiście, jaki jest temat, jakie są zagadnienia poruszane, no, bo nie ukrywajmy, że [...] uczniowie poezji kompletnie nie rozumieją. (WP).

D/M: Wiem.

$\mathrm{Nl} / \mathrm{K}$ : Ktoś jeszcze? Jak tam, Oliwia?

$\mathrm{P} / \mathrm{M}$ : Ja też wiem.

Uczeń przerywa uczennicy i sygnalizuje werbalnie, że wie, choć nie był o to pytany. „Wtargnął” on niejako w przestrzeń komunikacyjną klasy szkolnej.

$\mathrm{O} / \mathrm{K}$ : Rozumiem, ale nie wiem, czy dobrze wiem.

Uczennica mówi to cichym i nieśmiałym głosem, jakby wiedząc, że jej rozumienie i wiedza nie są zgodne z oczekiwaniami nauczyciela. Wyraźna jest niepewność dziewczynki, co do jej wiedzy i sposobu rozumowania/wnioskowania oraz własnych kompetencji komunikacyjnych.

O/K: Czyli tego bogatego rycerza. (Z wątpliwością w głosie)

Nl/M: Nie, nie. Dobrze ci idzie, tylko żeś się gdzieś zgubiła po drodze. O/K: No i ten Bogart rycerz, wasal, wasal tego, tego.

Nl/M: Coś się żeś chyba zakręciła.

Zabrakło naprowadzenia uczennicy $(\mathrm{O} / \mathrm{K})$ przez nauczyciela. Może nauczyciel powinien pozwolić jej skończyć swoją wypowiedź sukcesem, co mogłoby być przejawem dobrej woli i/lub umiejętności metodycznych.

$\mathrm{O} / \mathrm{K}$ : I nie mogą robić, co chcą.

N1/M: Dobra. Podoba mi się wasz tok rozumowania.

Nl/M (po chwili): Być może to po dzisiejszej lekcji Weronika będzie kojarzyła.

Nl/M: To jest dział, w którym będziecie musieli myśleć i kojarzyć.

D/M: O jaaaa. Myśleć. Głowa będzie wszystkich bolała.

Nl/M: Trudno. Życie wymaga poświęceń. (LH)

6 Termin zapośredniczony z języka ekonomii. Oznacza dobro trudne do zdobycia z uwagi na jego cenę i dostępność. 
E/M: A małe pięciomiesięczne dziecko też pracowało?

$\mathrm{Nl} / \mathrm{M}$ : E/M, zanim zadasz głupie pytanie, pomyśl.

E/M: Ale ... . (Nauczycielskie przerywanie wypowiedzi).

$\mathrm{Nl} / \mathrm{M}$ : Zanim zadasz głupie pytanie naprawdę pomyśl.

E/M: To od ilu lat trzeba było pracować?

Nl/M: Nie wiem. Pożycz sobie Kodeks Hammurabiego i poczytaj.

Poniższe wypowiedzi obrazują różne drogi widzenia tej samej ilustracji, pozostające w przestrzeni nieakceptowalności nauczycielskiej.

D/M: Wygląda jak zaokrąglony prostokącik.

J/M: Jak elipsa.

$\mathrm{Nl} / \mathrm{K}$ : Zaokrąglony prostokąt? (Z ogromnym zdziwieniem i niezadowoleniem).

Właśnie w taki sposób zdaniem badaczki można było określić kształt tego czegoś, ale nie było to zgodne ze sposobem widzenia nauczycielki, bo tylko on jest prawomocny. Zdziwienie oraz niezadowolenie prowadzącej lekcję było negatywnym wzmocnieniem dla dalszych procesów myślowych uczennic i uczniów. Określenie i przybliżenie prawdy w słowach „Jak elipsa" może było mniej nieodpowiednie, ale również nie zasługiwało na akceptację. Dzieci nie wiedziały zdaniem nauczycielki, jak adekwatnie nazwać kształt oglądany na ilustracji, wiedziały natomiast, jak wygląda prostokąt, koło i elipsa i na tej wiedzy próbowały zbudować swoje jej widzenie. Krytyka, niezadowolenie i „negatywne” zdziwienie nauczycielki skutecznie tłamsi strumień spontanicznych aktów mentalnych będących „wodą” dla „spragnionej” wiedzy.

Powstająca w szkole wiedza nie zasługuje na miano „właściwej” wiedzy interpretacyjnej, gdyż ta w odczuciu nauczycieli nie charakteryzuje się krytycznym namysłem, „świeżym” przyglądaniem się złożoności świata, dostrzeganiem niejednoznaczności, implikacji rozmaitych stanów rzeczy oraz problematyczności osądów (Klus-Stańska 2002, s. 120). Poniższy fragment dość czytelnie obrazuje sposób myślenia nauczycielki o potencjalnościach uczniowskich procesów myślowych:

Nie przygotowują się. Oni, jeśli się zgłaszają, to zgłaszają się przez to, że posiadają jakąś wiedzę, nie wiem, z życia czy po prostu na czuja zgłosić się mogą, bo może mi się uda dostać plusa a nic złego mi się nie stanie, nie. (WS/K)

Nie ma myślenia, takiego abstrakcyjnego, że nie umieją wyobrazić sobie pewnych rzeczy, że oni muszą mieć konkrety, tu i w tym momencie to wygląda tak, i jeśli jeszcze nie mogą dotknąć to już przez takie właśnie namacalne rzeczy. (WP/K)

"Zarządzający” przestrzenią komunikacyjną w klasie szkolnej nie dostrzegają uczniowskiej zdolności do abstrakcyjnego myślenia, a także umiejętności „wyobrażenia sobie pewnych rzeczy”. Ponadto, „jeśli nie mogą dotknąć” badanej rzeczywistości, to potrafią poruszać się jedynie w świecie „konkretów”. 
Kolejna ujawniona w materiale empirycznym kategoria w formie „interesującego" połączenia aktów mowy jako kolejny czynnik nie sprzyja spokojnemu, swobodnemu oraz spontanicznemu konstruowaniu wiedzy w klasie szkolnej.

Nl/K: A jeśli, coś nam się szczególnie podoba, jesteśmy w jakimś naprawdę pięknym miejscu, to my to staramy się właśnie jak najdłużej zapamiętać i to nam daje też taka siłę do działania. Ja mam wrażenie, że po was, jak po kaczce, wszystko spływa, że wy jakichś uczuć, emocji w ogóle nie odczuwacie. (Po tych aktach mowy pojawiła się kilkuminutowa cisza).

Szkoła uczy stosowania „dyskursywnego kontrastu”, gdzie w powyższym fragmencie wypowiedzi nauczycielki zauważyć można zestawienie zachwytu „pięknym miejscem” ze strumieniem krytyki dotyczącej [nie]zdolności odczuwania emocji przez uczennice i uczniów: „po was, jak po kaczce, wszystko spływa". Konstrukcja i treść owego zestawienia aktów mowy nie jest radosnym i inspirującym czynnikiem do aktywnego wysiłku intelektualnego. Z kolejnym podobnym kontrastem spotykamy się w poniższym fragmencie wypowiedzi nauczycielki.

Nl/K: To takie, kiedy my czegoś nie znamy, czyli mamy lęki i obawy, bo nigdy nie wiemy, tak, jak ten świat wygląda w rzeczywistości. Nawet, jeżeli mamy jakąś wiedzę książkową, to i tak doświadczenie czasami weryfikuje to, co my wiemy, tak? Zdolny to jest ktoś, kto ma nie dość, że bogatą wiedzę, ktoś, kto jest inteligentny i potrafi się posługiwać swoim umysłem, no. A jam mam wrażenie, że wy jesteście ... (tu zawieszenie głosu nauczycielki), nawet ja nie wiem.

Sposób, w jaki nauczycielka przekazuje wiedzę dzieciom to „takie podawactwo, że tyle i nic ponad to". Prosta, niczym niezakłócona transmisja wiedzy, realizująca się poprzez podawanie gotowych opisów, sądów, refleksji, interpretacji i znaczeń, bo umysły uczennic oraz uczniów „nie są przygotowane na wyrafinowane" metody nauczania, które mogłyby ułatwić im „atrakcyjne” konstruowanie wiedzy połączone $\mathrm{z}$ samodzielnym nadawaniem znaczeń.

Nl/W/K: [...] Mam wrażenie czasami, że to jest taka, takie podawactwo, że tyle i nic ponad to.

Wiedza, którą obdarowują uczennice i uczniów nauczycielki i nauczyciele nie służy równemu oraz zrównoważonemu rozwijaniu zdolności dziewcząt i chłopców do stania się w przyszłości obywatelką i obywatelem globalnej demokracji ze świadomością aspektów: fizycznego, duchowego oraz kulturowego życia poza murami szkoły (Giroux 2010, s. 97). Zatem sposoby widzenia i rozumienia zachowania się wiedzy w szkole, wewnątrz intelektów nauczycielek, nauczycieli, uczennic i uczniów są uszeregowane w hierarchicznym porządku, od wiedzy po śladzie, do marzeń o innych sposobach traktowania wychowanków oraz siatki [nie]samodzielnie nadawanych otaczającej rzeczywistości znaczeń.

Zdaniem nauczycielki, co można wnioskować z poniższego fragmentu, intonacji głosu oraz mimiki, zainteresowania związane $\mathrm{z}$ modą uczennicy w wieku 
12-13 lat wzbudzają wątpliwości, jednakże nie tak duże, jak interesowanie się uczniów "jakąś seksualnością nawet". Kontynuując sposób myślenia o zainteresowaniach uczennic, podkreślić należy, iż nie mają one „takiego oglądu tego świata”, który cechowałby się takimi parametrami, jakie w oczach nauczycielki znalazłyby uznanie.

Wydaje mi się, że nie ma takiego oglądu tego świata, że oni mają zainteresowania [...], może jedni tam związane z modą. Inni się tam już z jakąś seksualnością nawet, do tego stopnia, że, że, no, właśnie te takie horyzonty nie są jakieś takie. (WP/K)

Zatem analizując zbiór powyższych fragmentów, powiedzieć można, iż narzucona zostaje dydaktyka "skażona” kategorią wiedzy po śladzie, bo taką jest wiedza większości uczniów oraz uczennic (Klus-Stańska 2002, s. 120, 123-124), zgodnie z logiką pola, w którym funkcjonują pod wpływem obiektywnych sił. Skonfigurowana w jej oparciu logika interakcji komunikacyjnych działań w umysłach uczniów oraz uczennic konstruuje znaczenia pozostające w stosunku spójności z zawodowym illusio („praktyczną wiarą”) nauczycielek, które jest nie tylko usprawiedliwieniem dla stosowania ograniczonych praktyk pedagogicznych (Bourdieu, Wacquant 2001, s. 87), ale również pewnego rodzaju „legitymacją" do utrwalania habitusowych nierówności społecznych (Kopciewicz 2007, s. 107).

Specyfika budowania i ożywiania wiedzy na lekcjach religii nie odbiega od jej trajektorii na innych lekcjach. W świetle tego, co mówią przedstawiciele Kościoła, nauczycielom religii bardzo zależy na przybliżeniu uczennicom i uczniom problematyki związanej z rodziną, Bogiem oraz wiarą. Konstruowanie wiedzy o Bogu oraz relacji z nim, jakiej dzieci uczone są nie tylko w domu i kościele, zaprezentowane jest w poniższym fragmencie.

Z/M: Czemu ja nie wierzę w Boga?

$\mathrm{Nr} / \mathrm{M}^{7}$ : Uspokój się!

$\mathrm{Z} / \mathrm{M}$ : A czym to grozi?

$\mathrm{Nr} / \mathrm{M}$ : Lepiej żebyś ... .

Uczeń klasy szóstej (chłopiec) na lekcji religii zadał nauczycielowi pytanie o proweniencji eklezjologicznej: "Czemu ja nie wierzę w Boga?”, oczekując na nie konstruktywnej odpowiedzi. Po chwili otrzymuje niesatysfakcjonującą go odpowiedź: „Uspokój się!” Znaczenie powyższego responsu uwydatnia wykrzyknik, który symbolizuje podniesiony głos odpowiadającego, połączony ze zdenerwowaniem oraz niezadowoleniem. Uczeń wobec tak skonstruowanej odpowiedzi wygenerował kolejne pytanie: „A czym to grozi?”. Zapytał, czym grozi wypowiadanie pytań związanych z niewiarą młodego człowieka w Boga? Nakaz uspokojenia się przez ucznia nie jest dla niego zadowalającą odpowiedzią na tak postawione pytanie, gdyż nie daje mu żadnej wiedzy na temat, czym rzeczywiście grozi bycie odważnym w stawianiu „niestosownych” pytań. Uczeń usłyszał:

\footnotetext{
$7 \mathrm{Nr} / \mathrm{M}$ - nauczyciel religii, mężczyzna.
} 
„Lepiej, żebyś ...". Z dużą odpowiedzialnością stwierdzić można, iż tak konstruowany po stronie nauczyciela dialog nie służył ani budowaniu wiedzy o Bogu, a tym bardziej relacji z nim młodego chrześcijanina.

$\mathrm{Nr} / \mathrm{M}[\ldots]$ Czego my, jako ludzie pragniemy, jako dobra materialnego?

C/M: Dobrego mózgu.

$\mathrm{Nr} / \mathrm{M}$ : Wiedza (z zadumą).

W duchu rozważań eklezjologicznych nauczyciel zapytał uczniów i uczennice: „Czego my, jako ludzie pragniemy, jako dobra materialnego?" Dziewczęta milczały, jednakże jeden z uczniów stwierdził, że „dobrem materialnym, którego pragnie" jest "dobry mózg" taki, który wraz z intelektem będzie samodzielnie konstruował wiedzę i nadawał znaczenia otaczającej rzeczywistości materialnej oraz „eklezjologicznej”.

J/M: Najlepiej jest na matematyce.

W przypadku lekcji matematyki można mówić o dużym stopniu koncentracji niemal wszystkich uczennic i uczniów na wykonywanym zadaniu. Nauczycielka jest zaangażowana w każdy matematyczny krok dzieci. Chłopcy postrzegani są przez matematyków jako zdolniejsi w tej materii, dlatego też w powyższym fragmencie uczeń stwierdza, iż jeśli chodzi o najbardziej pozytywnie oceniany sposób komunikowania się nauczycielki z uczniami, to „najlepiej jest na matematyce”.

\section{Umiejscowienie illusio w dyskursywnym konstruowaniu wiedzy w przestrzeni budowania habitusu męskiego}

Umysł ludzki jest społecznie formowany i jednocześnie zamknięty w swych granicach. Marks nazywał je granicami systemu kategorii, które "wdrukowane" zostały człowiekowi $\mathrm{w}$ społecznym procesie kształcenia (Bourdieu, Wacquant 2001, s. 113). Przez owe społecznie skonstruowane granice podmiot nie jest w stanie całościowo postrzegać i rozumieć sytuacji przede wszystkim wtedy, gdy mamy do czynienia z presją działania. Język szkoły wyznacza ramy wiedzy, jaką zdobywają uczennice i uczniowie, które podpowiadają, jak postrzegać rzeczywistość i narzucają interpretację efektów procesu poznawania. Ramy te są poddawane ciągłym i nieustannie trwającym uzgodnieniom (Kwaśnica 1987, s. 56). Uczennice oraz uczniowie dokonują swej "samokonfiguracji” w polu społecznym zgodnie z gramatyką socjalizacyjną, co nie powinno przeszkadzać uczniowi w samodzielnym, zmodyfikowanym indywidualną optyką, nadawaniu znaczeń. Wszystko, co człowiek potrafi zobaczyć i przekazać za pośrednictwem języka właśnie od niego zależy, od języka, ale również od człowieka, jakim jest uczeń oraz uczennica (Kwaśnica 1987, s. 56). 
Są dzieci świadome i cokolwiek im się powie to one przyjmą, przetrawią i same ewentualnie wyciągną wnioski. [...] uczymy, [...] jeśli uda nam się pewne rzeczy zaszczepić konsekwencją, to one to będą robiły automatycznie [...]. Wtedy oni zauważą, ile one wiedzą i jak bardzo różną one wiedzę mają. (WH/M).

„Świadomość językowa" jednostki prawdopodobnie zmniejsza ograniczenia, które niesie świat symboli i daje szansę na dostrzeżenie przyczyn słabej ostrości nie tylko szkolnego obrazu świata (Bourdieu, Wacquant 2001, s. 16). Ofiarami języka, a także jego granic, są jego użytkownicy, którzy (bardziej lub mniej świadomie) godzą się, aby objęły one swym zasięgiem również rozumienie i nadawanie znaczeń (Bruner, 2006, s. 36) w ramach gruntowego przekonania (illusio), że wszystko toczy się według pragmatycznego porządku ujarzmiania.

Powiedzieć, jak już coś wiedzą, a czasami mało wiedzą. Mało mają możliwości, żeby się popisać tym, że wiedzą, to wtedy chcieliby mówić dużo i od razu, jak już coś wiedzą. $(\mathrm{WP} / \mathrm{K})$

Jeśli dziecko uczy się wyłącznie tego, co jest z lekcji, jeśli się uczy, to ten kontekst jest dużo mniejszy, więc jeśli zadam inaczej pytanie, może się okazać, że dziecko nie wie, bo nie zapytałem od tej strony, od której ono się uczyło [...]. (WP/M)

[...] Można pozwolić tam sobie na jakieś odnoszenie się do jakichś doświadczeń, no, ale jest temat, który organizuje nam tą jednostkę lekcyjną. (WP/K)

Nauczycielka w powyższym fragmencie zwraca uwagę na fakt, iż jej zdaniem pomocne mogą być uczennicom i uczniom w procesie uczenia się „jjakieś doświadczenia”, „no, ale jest temat, który organizuje nam tą jednostkę lekcyjną", co oznacza, że czas jest przeznaczany na temat lekcji, lecz nie na "odnoszenie się do jakichś doświadczeń". W "utajnionym” rozumieniu ucznia posługiwanie się swoim umysłem to proces wykorzystywania go w wybrany przez siebie sposób. Zatem znaczenie, jakie nadaje tej kategorii nauczyciel w polu klasy szkolnej, nie sprzyja rozwojowi samodzielnego uczenia się, decydowania o sposobach dochodzenia do jednej prawdy oraz do wielu prawd $w$ drodze wolnego wyboru nie jednego, lecz zbioru algorytmów do nich prowadzących. Odnalezione w powyższych fragmentach urzeczywistnianie monologowego „paradygmatu” w dyskursywnym polu klasy szkolnej odbywa się również w oparciu o konstruowane, zgodne z logiką pola, milczenie. Ponadto pamiętać należy, iż niemal w każdym akcie mowy nauczycielki/nauczyciela, czytelnie wymaga się od uczniów "posłuszeństwa” w myśleniu oraz oczekiwanym, dozwolonym nadawaniu znaczeń (Klus-Stańska, 2002, s. 94).

$\mathrm{Nl} / \mathrm{W} / \mathrm{K}$ : Nie zmuszamy ich do jakiegoś myślenia i wysiłku intelektualnego.

J/M: Nie chce im się myśleć. (Uczeń o swoich koleżankach i kolegach).

Ten fragment wypowiedzi nauczycielki podkreśla, iż chłopcy i dziewczęta "nie są zmuszani/zmuszane do myślenia i wysiłku intelektualnego". Jednakże uczniowie chętniej niż uczennice, a także bardziej samodzielnie taki wysiłek 
podejmują oraz są aktywizowani w tym kierunku. W przypadku dziewcząt nie obserwuje się znaczącej atencji nauczycieli i nauczycielek w zakresie „pozytywnego bodźcowania" ich intelektów.

Nl/M: Na razie robisz dobre wrażenie, a te możliwości, które masz, widać ewidentnie, że się nie uczysz. To są bardzo proste rzeczy, wiesz? (LH1/M)

Powyżej przytoczony fragment wypowiedzi nauczycielki zawiera krytykę lenistwa ucznia, lecz nie jego możliwości intelektualnych, jak to ma miejsce w przypadku dziewcząt.

$\mathrm{Nl} / \mathrm{K}: \mathrm{O} / \mathrm{K}$ ! Ty nie myśl, tylko pisz. Co myślałaś, że co?

$\mathrm{O} / \mathrm{K}:$ Że będziemy odmieniać czasowniki.

$\mathrm{Nl} / \mathrm{K}: \mathrm{O} / \mathrm{K}$ ? Co ty dzisiaj jesteś niemowa?

$\mathrm{M} / \mathrm{K}$ : Są (dziewczęta) mądrzejsze.

$\mathrm{J} / \mathrm{M}$ : Ja myślę, że nie.

Nl/K: Tak. Nos jest przy sercu. Wiek sędziwy ze wzrostem. Znowu wszystko wymieszane, zmiksowane i nadaje się do, yyy.

M/M: Do zupy.

Nl/K: Do zupy. No, my nie gotujemy zupy. My tworzymy opis. (LP1)

J/M: Udało się.

Nl/M: Nie. Dlaczego? (Cisza)

$\mathrm{Nl} / \mathrm{K}$ : Weź rozwiń tę swoją wypowiedź. Tak odpowiadają dzieci w trzeciej klasie, nawet nie wiem czy ....

$\mathrm{Nl} / \mathrm{K}$ : To wam trzeba wszystko, Iza, na talerzu podać. Ja mam wrażenie, że czekacie na gotowe, tylko sztućce i do jedzenia. Co to jeden J/M jest w klasie? A tekst jest taki skomplikowany? Słuchajcie. Minął miesiąc nauki, a po miesiącu nauki po prostu u was zamiast lepiej, to jest gorzej. Ja już nie wiem naprawdę. Może dojdzie do tego, że będziemy w kwietniu, weźmiemy klocki Lego i będziemy układać. Może to was zainteresuje? /Podniesionym głosem/. Patrzycie na mnie, jak na tego przybysza z kosmosu. /J/M zgłasza się./ (LP/K)

$\mathrm{Nl} / \mathrm{K}$ : Co się stało?

K/M: On przeczytał lekturę!

Nl/K: Nooo. Krzysiu, pochwal się pani, co zrobiłeś. Ja już myślałam, że masz coś na sumieniu. A tu takie piękne rzeczy mnie spotykają. No, to dobrze.

$\mathrm{P} / \mathrm{K}:$ Całą?

$\mathrm{Nl} / \mathrm{M}$ : Uczysz się na konkretnym przykładzie, a nie na ogólnym przykładzie (z irytacją). Co ja mówiłem? Co podkreślasz? Masz podkreślać od siebie.

$\mathrm{Nl} / \mathrm{K}$ : Całą, całą. No, widzisz. P/K. Wczoraj go nie było. Być może potrzebował jeden dzień więcej. ( $\mathrm{LP} / \mathrm{K})$

Wiedza interpretacyjna powinna opierać się na tym, co już uczniowie oraz uczennice wiedzą o polu szkoły i szerokim świecie społecznym. Jednakże wiedza oferowana młodym umysłom przez szkołę nie zasługuje na miano interpretacyjnej, gdyż ta charakteryzuje się krytycznym namysłem, „świeżym” przyglądaniem się złożoności świata, dostrzeganiem niejednoznaczności, implikacji rozmaitych 
stanów rzeczy oraz problematyczności osądów (Klus-Stańska 2002, s. 120). Poszczególne elementy badanego pola powiązane są w sposób mniej lub bardziej ścisły zgodnie z logiką pola społecznego Bourdieu, odnoszącą się zarówno do „trajektorii" dyskursu, jak i zachowywania się w jego przestrzeni wiedzy.

Dominujący sposób użycia języka w klasie szkolnej, zhierarchizowany rodzajowo, nakreśla bardziej to, co istotne w zakresie patriarchalnej logiki pełnionych ról przez kobiety i mężczyzn, zarówno w sferze prywatnej, jak i publicznej oraz to, co kolektywne, a nie jednostkowe. Jego dodatkowym walorem jest fakt, że dostarcza potencjału, na którym wyrastają/pojawiają się oczekiwane znaczenia. „Porządkująco na to, co, kiedy i jak się mówi wpływa charakterystyka stosunków społecznych, rygor uJarzmiania jednostek, narzucając im pozycję i ścieżki do kobiecości, męskości oraz sposobu bycia i działania w szeroko pojętym polu społecznym. Uczniowie (chłopcy) są uczeni posługiwania się urodzajowionym kodem językowym, umiejscawiającym ich w przestrzeni szans dokonywania wyboru spośród ogromnego spektrum form syntaktycznych i wykorzystywania go na setki sposobów zgodnie z logiką męskiej dominacji. Jednakże wybór dokonywany przez uczniów jest ograniczony, gdyż nie jest w pełni efektem świadomego poszukiwania „małego badacza”, a ponadto nie jest osadzony w zespole czynników genetycznych, lecz „magii parametrów” kulturowych.

Poprzez szkolny sposób konstruowania wiedzy skrzywdzeni zostają zarówno uczniowie, jak i uczennice. „Zafałszowana” nauczycielska interpretacja potencjału przestrzeni dyskursywnej w tym zakresie niemal doskonale ukrywa wszystkie założenia „cichej” polityki rodzaju, kierując myślenie dzieci w stronę „papierowej” równości. Przedmiotowe traktowanie uczniów, a zwłaszcza uczennic, przez nauczycielki i nauczycieli zmierza ku jednoznaczności czytelnego rozumienia pełnionych ról i ich granic. Językowe uwikłanie w narzuconą trajektorię powstawania tożsamości młodego człowieka zamyka krąg znaczeń, co pociąga za sobą implikacje, nie tylko w zakresie narzucania „instrukcji obsługi” tworu, jakim jest wiedza, ale przede wszystkim w sferze społecznej oraz psychologicznej.

Podział dzieci uczących się na grupy rodzajowe jest odzwierciedleniem przemyślanego oraz dyscyplinującego konfigurowania pola społecznego, zgodnie z linią społecznego podziału osiągnięć, aktywności oraz [nie]działań. Za McLarenem (2006) dobrze byłoby przyjąć, że wiedza o tym, że „to coś jest właśnie tym czymś", jest podpowiedzią a nawet wskazówką, jak należy się wobec "tego czegoś” zachować oraz w jaki sposób o „tym czymś” i o danym zachowaniu myśleć. Szkolny sposób obchodzenia się z wiedzą i jej wartościowanie nadaje jej charakter publiczny uwikłany w proces dystrybucji i usytuowaniu władzy w przestrzeni społecznej. Zatem można przyjąć, iż pole szkoły z panującym w nim androcentryzmem stwarza „odpowiednie” warunki nie tylko odtwarzania właściwych mu stosunków sił, ale również znaczeń w precyzyjnie określonych ramach (framing). Owe ramy odnoszą się realizowanego zakresu kontroli nauczyciela oraz ucznia, ustanawiania tempa oraz czasoprzestrzennej konfiguracji wiedzy oferowanej i reprodukowanej w dyskursywnych urodzajowionych praktykach pedagogicznych (Bernstein 1990). 
Elementarne formy świadomości i intencjonalności umiejscowione w zachowaniach oraz doświadczeniach percepcyjnych ucznia ukazują, iż ich relacja ze szkolną wiedzą pozostaje $\mathrm{w}$ harmonii $\mathrm{z}$ nauczycielskim tradycyjnym sposobem myślenia o zhierarchizowanym rodzajowo algorytmie jej „przekazywania” i kontrolowania. Każda jednostka jest posiadaczem sieci elementów intencjonalności, które ukazują zbiór władz mentalnych nad sposobami interakcji ze światem, zaś dyspozycje i zdolności zawarte w habitusach rodzajowych podmiotów edukacji budują ich tło. Uwidoczniony w materiale empirycznym opór uczniowski stanowi ważny konstrukt teoretyczny oraz ideologiczny, postrzegany przez nauczyciel$\mathrm{ki} /$ nauczycieli w optyce moralnego oraz politycznego oburzenia. Znaczenie zachowania opozycyjnego uczniów (chłopców), którzy częściej od dziewcząt dokonują dyskursywnych aktów oporu, nie powinno być łączone z dewiacją, patologią, bezsilnością, lecz przez nauczycieli jest. Nauczycielski sposób widzenia intencjonalności, świadomości i znaczeń stanowiących główne kategorie zakorzenione w logice oporu (Giroux 2010, s. 137) pozostaje zgodny z tradycyjną "gramatyką" życia szkoły. Perspektywa emancypacyjnej racjonalności ujawniająca się w świadomości uczniów w paralelnych procesach konstruowania wiedzy oraz męskiego habitusu potrzebuje rzetelnej definicji oporu, „oczyszczenia” nauczycielskiej [nie]wrażliwości, nowego sposobu widzenia podmiotu oraz swobodnej, a zarazem niekonformistycznej refleksji w kontekście niewypaczonych podstawowych wartości ludzkich.

\section{Literatura:}

Barker Ch., 2005, Studia kulturowe. Teoria i praktyka, tłum. A. Sadza, Wyd. Uniwersytetu Jagiellońskiego, Kraków.

Barnes D., 1988, Nauczyciel i uczniowie. Od porozumiewania się do kształcenia, tłum. J. Radzicki, WSiP, Warszawa.

Bernstein B., 1990, Odtwarzanie kultury, PIW, Warszawa.

Bochno E., 2009, Stereotyp ptci czy płeć języka? Szkolne interakcje komunikacyjne nauczycielek z uczennicami i uczniami [w:] Koniec mitu niewinności. Płeć i seksualność w socjalizacji i edukacji, L. Kopciewicz, E. Zierkiewicz (red.), Wyd. Psychologii i Kultury ENETEIA, Warszawa.

Bourdieu P., 2008, Zmyst Praktyczny, tł. M. Falski, Wyd. Uniwersytetu Jagiellońskiego, Kraków.

Bourdieu P., Wacquant L., 2001, Zaproszenie do socjologii refleksyjnej, Oficyna Naukowa, Warszawa.

Brannon L., 2002, Psychologia rodzaju, Kobiety i mężczyźni: podobni czy różni?, tłum. M. Kacmajor, Gdańskie Wydawnictwo Psychologiczne, Gdańsk.

Bruner J.S., 1980, Ontogeneza aktów mowy [w:] G.W. Shugar, M. Smoczyńska (red.) Badania nad rozwojem jezzyka dziecka, PWN, Warszawa.

Bruner J., 2006, Kultura edukacji, Wydawnictwo Universitas, Kraków.

Foucault M., 2009, Nadzorować i karać. Narodziny więzienia, tłum. T. Komendant, Wyd. Aletheia, Warszawa. 
Galasiński D., 2008a, Dyskurs a nieznośna lekkość psychopatologii [w:] Krytyczna analiza dyskursu. Interdyscyplinarne podejście do komunikacji społecznej, A. Duszak, N. Fairclough (red.), Wyd. Universitas, Kraków.

Galasiński D., 2008b, Men and the Language of Emotions, Palgrave Macmillan, UK.

Giroux H.A., 2010, Reprodukcja. Opór i akomodacja, [w:] H.A. Giroux, L. Witkowski (red.), Edukacja i sfera publiczna. Idee i doświadczenia pedagogiki radykalnej, Oficyna Wydawnicza „Impuls", Kraków.

Howe Chr., 1997, Gender and Classroom Interaction: A Research Review, SCRE, The Scottish Council for Research In Education, SCRE, Edinburgh.

Karwatowska M., Szpyra-Kozłowska J., 2005, Lingwistyka ptci. Ona $i$ on w języku polskim, Wyd. Uniwersytetu Marii Curie Skłodowskiej, Lublin.

Klus-Stańska D., 2002, Konstruowanie wiedzy w szkole, Wyd. Uniwersytetu Warmińsko-Mazurskiego, Olsztyn.

Konarzewski K., 1991, Problemy i schematy. Pierwszy rok nauki szkolnej dziecka, Wyd. Akademickie "Żak”, Warszawa.

Kopciewicz L., 2003, Polityka kobiecości jako pedagogika różnic. Kraków, Oficyna Wydawnicza „Impuls".

Kopciewicz L., 2007, Rodzaj i edukacja. Studium fenomenograficzne z zastosowaniem teorii społecznej Pierre'a Bourdieu, Wyd. Naukowe Dolnośląskiej Szkoły Wyższej Edukacji TWP, Wrocław.

Kruszewski K., 1993, 45 minut, czyli prawie cała historia jednej lekcji, Wyd. Naukowe PWN, Warszawa.

Kwaśnica R., 1987, Dwie racjonalności. Od filozofii sensu ku pedagogice ogólnej, Instytut Kształcenia Nauczycieli im. Władysława Spasowskiego w Warszawie, Oddział Doskonalenia we Wrocławiu.

McLaren P., 2006, Life in Schools, Pearson, New York.

Melosik Z., 2006, Kryzys męskości w kulturze wspótczesnej, Oficyna Wydawnicza „Impuls”, Kraków.

Pankowska D., 2004, Wychowanie a role ptciowe, Gdańskie Wydawnictwo Psychologiczne, Gdańsk 2004, Gdańsk.

Piaget J., 1996, Studia z psychologii dziecka, PWN, Warszawa.

Putkiewicz E., 2002, Proces komunikowania się na lekcji, Wydawnictwo APS, Warszawa.

Swann J., 2004, Schooled Language: Language and Gender In Educational Settings [in:] J. Holmes, M. Meyerhoff (eds.), The Handbook of Language and Gender, Oxford: Blackwell Publishing.

Sunderland L., 2000, New Understandings of Gender and Language Classroom Research: Text, teacher Talk and Student Talk, "Language Teaching Research", Vol. 4, No. 2.

Sunderland J., 2006, State of the Art Review article: Gender, Language and Language Education, „Language Teaching”, Vol. 33, No. 4.

Swann J., 2008, Talk Control: An Illustration from the Classroom of Problems in Analysing Male Dominance of Conversation, in Language and Gender, J. Coates (ed.), Blackwell Publishing.

Sztejnberg A., 2006, Profesjonalna baza wiedzy nauczyciela, [w:] Komunikacyjne środowisko nauczania i uczenia się, Wrocław, Wyd. Astrum. 


\section{Summary}

Discursive construction of school knowledge within the logic of a male habitus

This articles is an exploration of the ways in which school knowledge structures and is structured by norms of masculinity. It arose out of an interest in how participation in lessons can serve as a masculinizing practice - a practice that helps shape, reinforce and validate the constructions of certain versions of masculinities - and how boys construct identities that are consonant or at odds with this practice.

Keywords

gender, knowledge, inequality, habitus, school

Słowa kluczowe

gender, wiedza, nierówność, habitus, szkoła 